\title{
IMPACT OF SELECTED RURAL DEVELOPMENT PROGRAMMES ON POVERTY ALLEVIATION IN IKWUANO LGA, ABIA STATE, NIGERIA
}

By

\author{
I.N Nwachukwu ${ }^{1}$ and C.I Ezeh ${ }^{2}$
}

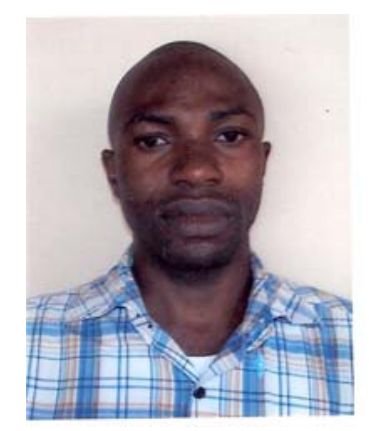

Ifeanyi Nwachukwu

*Corresponding author: Email: ifnwachukwu@yahoo.com

${ }^{1}$ Dept. of Agribusiness \& Management, Michael Okpara University of Agriculture, Umudike, Abia State, Nigeria.

${ }^{2}$ Department of Agric. Economics \& Ext, Abia state University Umuahia Campus, Abia State, Nigeria. Email: chimaezeh@yahoo.com 


\section{ABSTRACT}

Rural development is a veritable tool for fighting poverty and achieving economic prosperity at the grassroots level. The concept of rural development embraced by most countries connotes a process through which rural poverty is alleviated by sustained increases in the productivity and incomes of low - income workers and households. The major thrust of this study was to examine the impact of selected rural development programmes in Ikwuano Local Government Area of Abia State, Nigeria. The area under study was purposively selected because of its agricultural potential, high proportion of farmers as well as concentration of agricultural institutions. The selection of programmes for the study was impinged on their long years of existence.

The study sought to determine the number of available rural development programmes with poverty alleviation objectives in the area; assess the extent of awareness and participation of rural people in the programmes; and examine the impact of the programmes on farmers' income, farm size, production and productivity. Multi - stage random sampling method was employed in the selection of communities and respondents. A well-structured questionnaire was used to elicit responses on socio - economic characteristics and other relevant variables from a random sample of 160 respondents comprising beneficiaries and non-beneficiaries from Ikwuano local government of Abia state, Nigeria.

The results showed that the rural development programmes which had poverty alleviation objectives impacted significantly on productivity and farm income at 5 percent level of probability. Awareness was perceptibly high while participation was more in Agricultural Development Programme (ADP), with an overwhelmingly percentage representation of about 79, than in others. Programme planners and implementers are therefore urged to intensify awareness creation among rural dwellers and adopt the use of community driven development approach (CDD) in the execution of rural development projects with poverty alleviation thrust. Government, at all levels, was advised to adopt price support policy that raises income of producers.

Key words: Rural Development Programme, Poverty Alleviation.

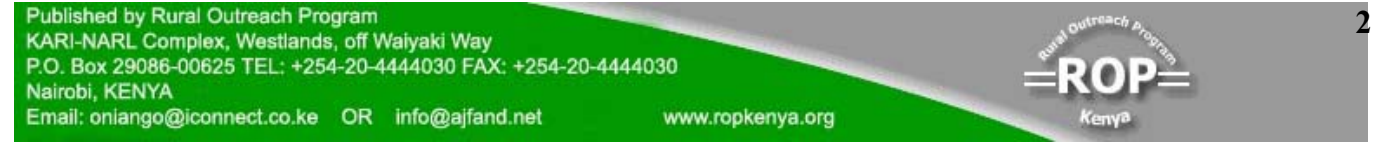




\section{INTRODUCTION}

Africa harbors most of the poorest countries (about 32) of the world because of so many factors such as wars and ethnic strife, natural disasters, foreign debts, corruption to mention but a few. Presently, Africa owes 350 billion dollars while Nigeria owes over 32 billion dollars. More so, the majority of citizens of sub - Saharan Africa are rural residents and depend on agriculture for a large share of their income. About $46.5 \%$ of her populations live below $\$ 1$ per day $[1,2]$. Surprisingly, Nigeria has enormous natural gas reserves, vast agricultural lands, natural resources and a dynamic private sector. Agriculture however employs over two - thirds of the population and accounts for a third of the GDP.

The average poverty incidence in Nigeria increased from 0.28 to 0.42 between 1980 and 1992 respectively and by 1996, the situation worsened to an average of 0.66 . By implication, out of every 100 Nigerians, 66 were dwelling below the poverty line with great difficulties [3,4]. On the basis of surveys on poverty by Federal Office of Statistics, the nature of poverty in Nigeria is overwhelmingly a rural problem. With average annual growth of $2.4 \%$ in population and $2.4 \%$ in labour force, Nigeria is yet to be out of the woods. Since 1990 , the country has been classified as a poor nation. The UNDP Human Development index (HDI) for 2000 ranked Nigeria as the $142^{\text {nd }}$ with HDI of 0.40 among the poorest countries. A study of Nigeria's national problems will give an inescapable conclusion that Nigeria's economic problems can only be solved through first, solving her agricultural problems via sustainable rural development $[5,8]$.

The true success of any comprehensive, economic and social development programme in Nigeria is primarily dependent upon the extent to which it contributes to the well being of those living in the rural areas. This is because the bulk of the country's population, resources particularly land, natural and mineral resources are in these areas. Much as the problem of rural poverty has been noted, even globally, there are yet controversies among policy makers on appropriate concepts of rural development and by extension, appropriate policies and strategies for eradication of rural poverty [9]. Various governments of Nigeria have tried several programmes, approaches and strategies aimed at improving the conditions of the rural poor and while some of the efforts are still on course, many have since gone moribund. Central in the varying objectives of the programmes was the target of alleviating poverty, which was heavily biased towards agriculture and rural development.

In the bid to ascertain the impact of some of these programmes on poverty reduction, this paper sought to: (i) determine the availability and the number of rural development programmes that have poverty alleviation motives in the study area; (ii) assess the extent (degree) of awareness and participation of rural people in the programmes; (iii) determine the impact of the selected programmes on farmers' income, farm size, production and productivity;(iv) make recommendations.

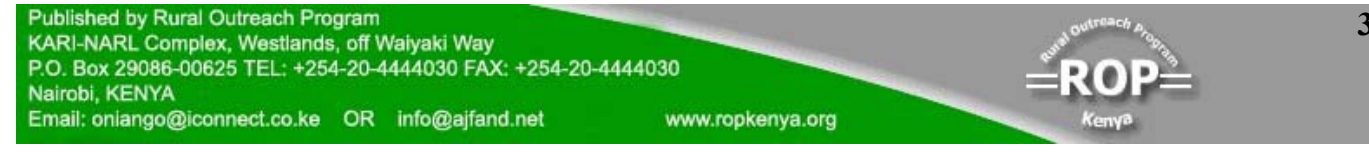




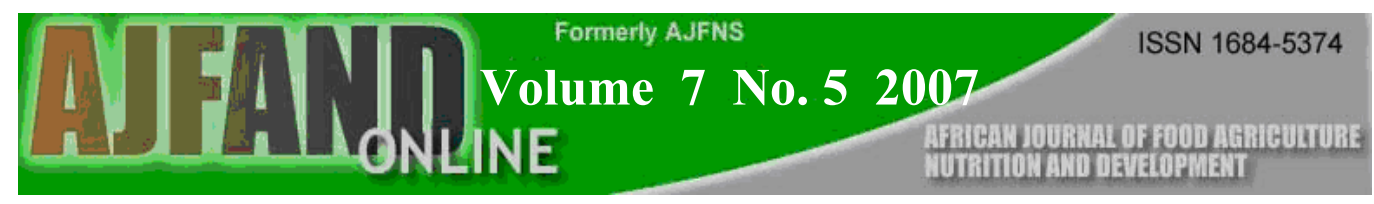

\section{CONCEPTUAL FRAMEWORK AND LITERATURE REVIEW}

Rural Development simply connotes a sustained improvement in the quality of life of the rural people. It implies consistency in approach in which micro and macro economic, social, political, cultural and technological variables are engineered, combined and implemented as an organic and dynamic whole for the benefit of the people. Rural development is used synonymously with agricultural development. This is because of the strong interrelationship between agriculture and rural development. Agriculture is a predominantly rural activity and efforts at rural development impact considerably on farmers who are the focus of agricultural development efforts. It is on this account that the integrated rural development projects in Nigeria were designed to ensure that agricultural and rural development efforts became part of a package of services offered to farmers and the rural population [10].

The bottom line really is poverty alleviation consequent upon increase in rural productivity, income and diversification of rural economy, improvement in the supply of rural infrastructure (physical, social and institutional), enhancement of social participation and radical improvement of the quality of life of the rural people. The concept of rural development has been broadened in recent times to accommodate non - economic issues, especially those relating to social, political, legal, cultural and environmental issues. This broadened rural development concept, otherwise known as the sustained rural development, takes a long - term view of which meets the needs of the present generation without compromising the needs of future generation [11].

Participation means the active involvement of communities in need assessment, determination of priorities, planning and execution of projects. It also refers to the contribution of potential beneficiaries to the realization of a project for their own development [12]. Community - based participatory approach to development is described as an umbrella term for anti - poverty programmes that involve the beneficiaries in their design and management. The key factor in participation is the incorporation of local knowledge into projects' decision-making process [13]. Participation is fruitful for sustainable change as an active process by which beneficiaries or client groups influence the direction and execution of development projects in order to enhance their well - being in terms of income, personal growth, self - reliance and other cherished values.

This study was based on the theory of rural development, which is a derivative of general theory of development. However, due to the peculiar character of rural areas, specific programmes and strategies are usually designed to address the problems of under-development and poverty [14].

\section{Poverty Programmes in Nigeria}

Poverty alleviation connotes a process of reducing poverty to a bearable level and not its total elimination. The concern over increasing poverty levels especially in the developing countries and the need for its alleviation as a means of improving the standard of living of the people has led to the conceptualization and implementation

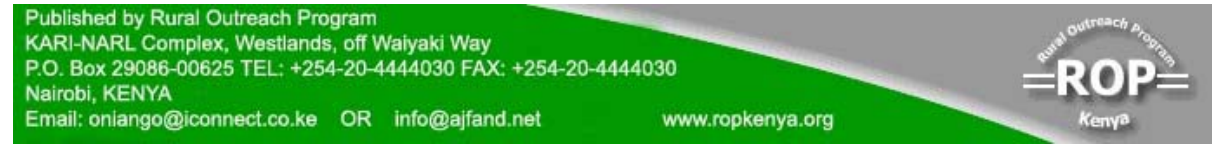




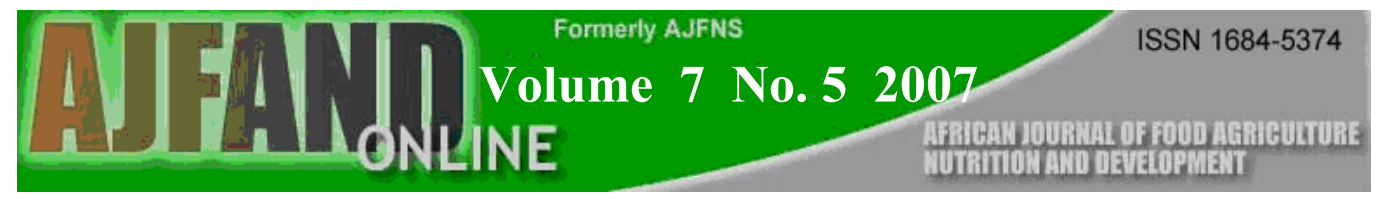

of various poverty alleviation programmes worldwide. In Nigeria, the government and donor agencies have been active in their efforts to analyze and find solutions to the menace of poverty. Some of the programmes implemented to alleviate poverty include the establishment of the Directorate of Food, Roads and Rural Infrastructure (DFRRI) with the major aims of opening up the rural areas and to improve the conditions of the vulnerable poor.

The Better Life Programme (BLP) was mostly gender specific; it was meant to improve the life of rural women. Harnessing the potentials of the rural women in order to boost their economic activities and improving their incomes were the goals of the programme.

The programme was later replaced by Family support Programme (FSP). FSP was almost the same with BLP especially in similarity of concept and identical objectives. The difference was that it embraced other members of the family.

Agricultural Development Programme (ADP) is a World Bank assisted programme in conjunction with the Federal Government and State Governments. Its principal aim was to boost the productivity of the peasant farmers through farm inputs supply, extension services and construction and maintenance of rural roads. It also fostered the establishment of cooperatives $[15,16]$.

The Abia state Agency for Community - Based Poverty Reduction project is a jointly funded project by the World Bank and Federal government of Nigeria, which acts as a safety net purveyor of funds to community designed and implementable projects. The projects range from the provision of electricity, water bore hole, feeder roads, health centers, classroom blocks, dormitories, markets to civic centers and agriculture.

Family Economic Advancement Programme (FEAP) was an employment programme designed specifically for locally based producers of goods and services and potential entrepreneurs in the establishment of cottage industries [17]. Its emphasis was laid on the economic development and empowerment of the rural populace particularly low income families, cooperatives through the provision of loans.

The National Special Programme on Food Security (NSPFS) is a targeted intervention programme of the Federal Government of Nigeria, developed with the collaborative efforts of Food and Agricultural Organization of the United Nations (FAO/UN). The expected outcomes of NSPFS include increased employment opportunities, reduced post harvest losses, improved standard of living, improved quality of life and economic status of farmers and rural dwellers $[18,19]$

\section{METHODOLOGY}

The study area was Ikwuano local Government Area of Abia state, Nigeria and was purposively selected because of its agricultural potential, high proportion of farmers as well as concentration of agricultural institutions. Ikwuano is located between latitude $5^{0} 24^{\prime}-5^{0} 30^{\prime} \mathrm{N}$ and longitude $7^{0} 32^{\prime}-7^{0} 37^{\prime} \mathrm{E}$ in southeastern axis of Abia

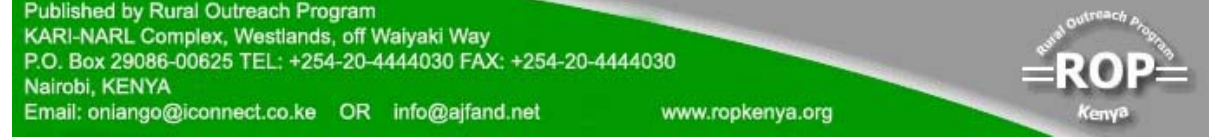


state. Multi - stage random sampling method was employed in the selection of communities and respondents. In stage 1, two (2) villages were randomly selected from the eight autonomous communities in the locality, making it a total of sixteen villages. In stage 2, 10 respondents were randomly chosen from each of the villages, which gave a total of 160 respondents. Eighty of the respondents were beneficiaries while others were non - beneficiaries. The selection of programmes was based on the fact that they were well - entrenched and had been in place for at least seven years.

Apart from the use of descriptive statistics, the study employed paired t-test statistics because of its suitability and applicability in assessing effects (impact) by comparing responses from beneficiaries and non - beneficiaries of the programmes. The adoption of paired t-test statistics was based on similar work, which assessed the impact of credit on total production, productivity, farm size and operating expenses as well as a paper that compared crop output, farm income, farm size and labour of Fadama (Hausa name for irrigable land) and non-Fadama farmers [20, 21]. The model is implicitly stated as

$$
\frac{\mathrm{t}=\frac{\overline{\mathrm{X}_{1}-\mathrm{X}_{2}}}{{\overline{\sqrt{\mathrm{S}_{1}}}}^{2} \mathrm{~S}_{2}^{2}}{ }^{+} \overline{\mathrm{n}}_{2} \mathrm{n}_{1}+\mathrm{n}_{2}-2 \quad \text { degree of freedom }}{}
$$

Where: $\quad \mathrm{t}=\mathrm{t}-$ test statistic

$\mathrm{X}_{1}=$ Mean value of the farmer beneficiaries of poverty alleviation programmes

$\mathrm{X}_{2}=$ Mean value of the non - farmer beneficiaries

$\mathrm{S}_{1}^{2}=$ Variance for beneficiaries

$\mathrm{S}_{2}^{2}=$ Variance for non - beneficiaries

$\mathrm{n}_{1}=$ Sample size of beneficiaries

$\mathrm{n}_{2}=$ Sample size of non - beneficiaries

In order to achieve objective 3 , it is hypothesized as follows:

Ho: There is no significant difference in farm production, productivity, farm size and farm income between farmer beneficiaries and non - beneficiaries of poverty alleviation programmes in Ikwuano local government area of Abia state, Nigeria

\section{RESULTS}

\section{Socio - economic Characteristics of Respondents}

The socio - economic profile of the respondents are presented in Table 1. With respect to age, $68.18 \%$ of the respondents fell within $41-60$ years age bracket. Married respondents accounted for $73.12 \%$ while $86.88 \%$ had different levels of 


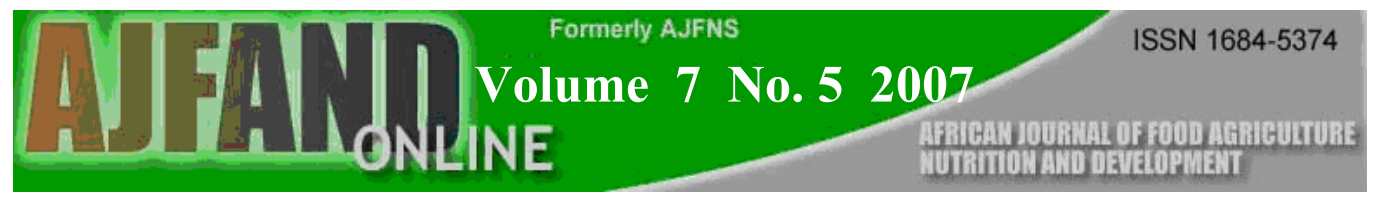

formal education. The dominant family size $(85 \%)$ was in the range of between 5 and 9 persons while $51.25 \%$ practised farming as their primary occupation.

\section{Availability and Number of Rural Development Programmes}

The available rural development programmes in the area and their year of commencement were Agricultural Development Programme (1975), Directorate of Food, Roads and Rural Infrastructure (1986), Better Life Programme (1981), Family Support Programme (1995), Family Economic Advancement Programme (1997), Abia State Agency for Community - Based Poverty Reduction Project (2000) and National Special Programme for Food Security (2001) (Table 2).

\section{Level of Awareness}

In terms of awareness, $66.63 \%$ of the respondents were aware of the existence of the programmes. About $34.37 \%$ were ignorant of their existence [Table 3].

\section{Participation}

With respect to the percentage of people involved in the rural development programmes, $79.05 \%$ participated in ADP; $1.90 \%$ were involved in FSP. In the multiple response cases where a respondent participated in more than one programmes, 3.81\% partook in both ADP and FSP; $1.90 \%$ took part in ADP, FEAP and FSP; $4.76 \%$ were part of ADP and FEAP; $2.86 \%$ participated in ADP and DFRRI; $0.95 \%$ each were involved in [FSP, ADP, FEAP \& BLP] and [ADP, FEAP \& DFRRI], respectively. In all the programmes, $3.81 \%$ of the respondents participated in them [Table 4]. 
Figure1:Percentage Participation in the Programmes

Percentage Participation in the Programmes

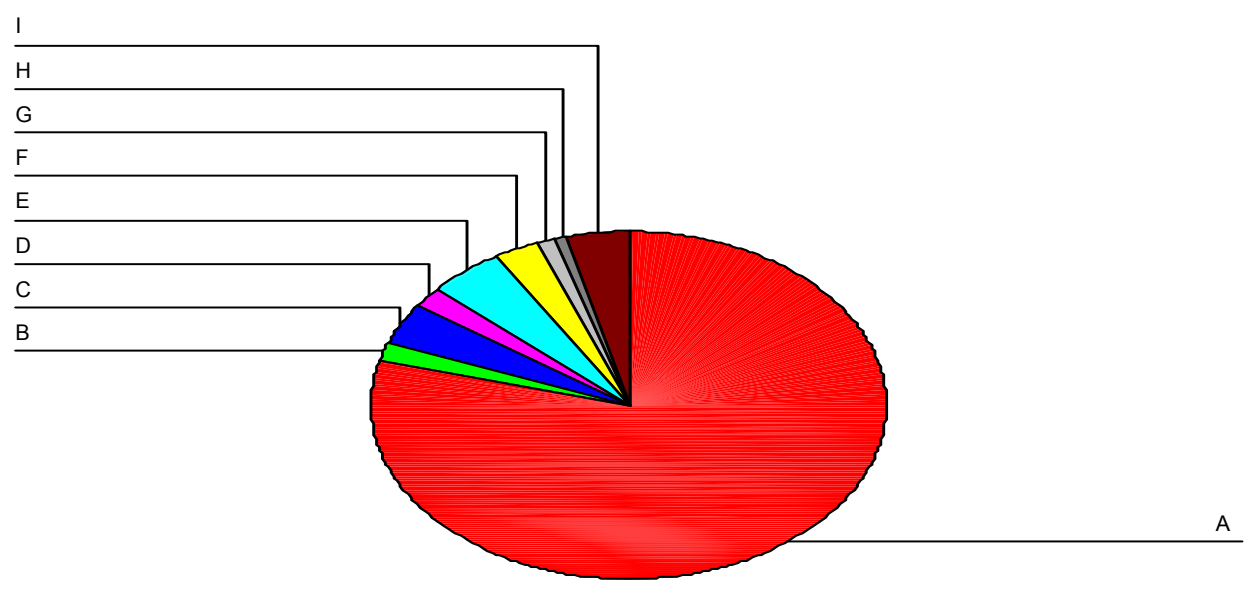

$$
\begin{aligned}
& \text { A - ADP }(79.05 \%) \\
& \text { B - FSP }(1.90 \%) \\
& \text { C - ADP \& FSP }(3.81 \%) \\
& \text { D - ADP, FEAP \& FSP }(1.90 \%) \\
& \text { E - ADP \& FEAP }(4.76 \%) \\
& \text { F - ADP \& DFRRI }(2.86 \%) \\
& \text { G - FSP, ADP, FEAP \& BLP }(0.95 \%) \\
& \text { H - ADP, FEAP \& DFRRI }(0.95 \%) \\
& \text { I - ALL }(3.81 \%)
\end{aligned}
$$

\section{Impact on Production, productivity, income and farm size}

The results of paired $\mathrm{t}$-test for production and productivity levels between beneficiaries and non - beneficiaries showed a mean difference of 3.09 tonnes and 0.32 tonnes, respectively. Mean differences for income and farm size were $¥ 33$, 703.65 and 3.73 ha, respectively. [Table 5].

\section{DISCUSSION}

The result of the socio - economic variables indicates that the majority $(68.18 \%)$ of the respondents fell within the age range of 41 and 60 years. This formed the cream of productive work force $[14,22]$. It also shows that majority $(73.12 \%)$ of the respondents were married while a modal response of $86.88 \%$ had different levels of formal education. The high level of literacy in the rural areas of Abia state, Nigeria demands special attention. The free education packages inherent in most poverty alleviation measures are very instructive. Human capital development holds the key to highly and sustainable agriculture [23]. The dominant (85\%) family size has some implications on the amount of labour available to the household for agricultural 


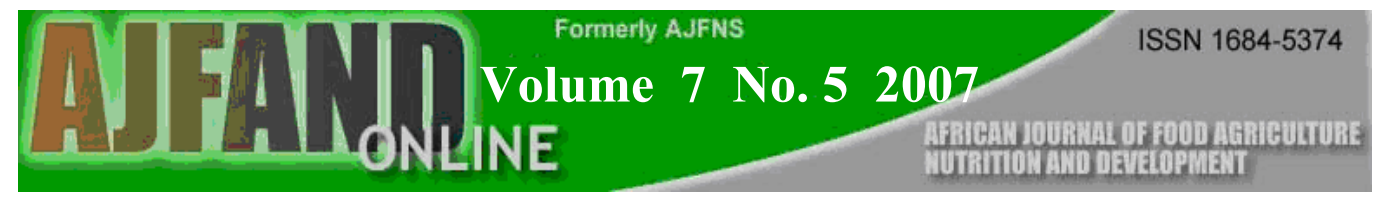

activities. Having $51.25 \%$ of the respondents as farmers in the area, their predominance explains why over $90 \%$ of the food produced in the country comes from the rural sector $[24,25]$.

Due to the depth and multi - faceted nature of poverty in the study area, nay Nigeria, the array of poverty alleviation programmes adopted and implemented by various administrations were aimed at stamping out completely the "monster" called poverty in Nigeria's landscape. Given their years of commencement, ADP is the oldest programme, which has survived numerous administrations.

In the area of awareness, majority $(66.63 \%)$ of the respondents were aware of the existence of these programmes. This implies a weak grass - root governmental information dissemination system. The fact that most of these programmes have been implemented for more than 2 decades and a good proportion $(34.37 \%)$ of the rural people were still not aware of their existence is unfortunate indeed.

In terms of participation, more $(79.05 \%)$ of the respondents participated in Agricultural Development Programme (ADP) than in other programmes. High level of participation in ADP must have been informed by the fact that it is the most popular which has been well entrenched in the area. The tendency of ADP agents to live in their areas of jurisdiction seemed to be a clear advantage [26].

The paired $\mathrm{t}$ - test for a difference in farm production, productivity, farm size and farm income of beneficiaries and non - beneficiaries of poverty alleviation programmes showed a remarkable scenario. Given the fact that the mean difference in the productivity of farmer beneficiaries and non - beneficiaries of poverty alleviation programmes was 0.32 (with a high $\mathrm{t}$ - value of 3.17 ), the result is statistically significant at 5.0 percent probability level. The mean annual farm income for beneficiary farmers was $\$ 4,748.37$ and the non - beneficiary farmers was $\$ 13$, 044.72 while the mean difference was $\$ 33,703.65$. The result was statistically significant at 5.0 percent level of probability. There is increased intensity of resource use among beneficiary farmers [27, 20]. This means that the hypothesis of no significant difference in farm income between the groups is rejected.

The mean differences in farm size and production variables of farmer beneficiaries and non - beneficiaries have $t$ - values (1.83 and 1.12, respectively) that were less than $\mathrm{t}$ - tabulated (2.00). As such, the variables were not statistically significant at $95 \%$ confidence level. The null hypothesis of no significant difference in farm size and production is therefore accepted.

\section{CONCLUSION AND RECOMMENDATIONS}

In Ikwuano local government area of Abia state in particular and Nigeria in general, poverty and its excruciating impact are pervasive and palpable on the people. With the projection made by the World Bank that poverty in Nigeria will increase by two thirds, and with the possibility of $60 \%$ of the population living below poverty line in 10 years [28], the government of Nigeria adopted the concept of poverty alleviation as

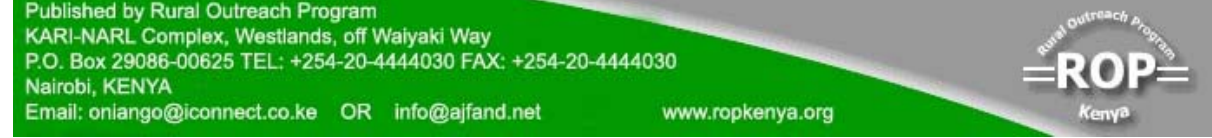




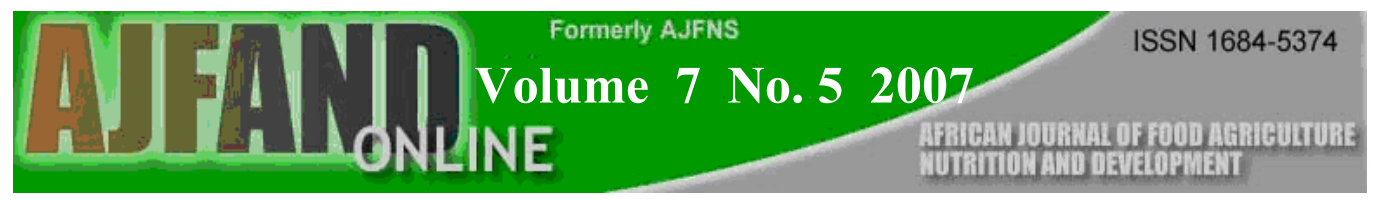

a major thrust of its annual budgets. The impacts are manifest especially in the area of productivity and farm income. In order to achieve pragmatic poverty reduction at the grass roots, the following recommendations will suffice:

(i) There is greater need for the government to embark on serious intensive awareness creation of the existence of these poverty alleviation programmes through the use of village/town criers, village meetings, radio and television jingles in local dialect.

(ii) Policy makers should de - emphasize the issue of top - down flow of information. This approach has the great disadvantage of reducing interaction between policy makers and the rural dwellers as well as participation. Community Driven Development Approach (CDD) should rather be used as this medium offers the rural people the opportunity to actively involve in the entire process of conception, identification, and execution of any poverty alleviation programme that will benefit them.

(iii) Government should adopt price support policy that keeps the prices of commodities up to a minimum level. Such a policy will impact on income of the rural producers. 
Table 1: Socio-Economic Characteristics of Farmers in Ikwuano (2006)

Age (in yrs)

Below 20

$21-40$

$41-60$

61 and above

Total

\section{Marital Status}

Single

Married

Widowed

Divorced

Total

\section{Education}

No formal Education $\quad 21$

Primary Educ. Incomplete $\quad 37$

Primary School Completed 54

Secondary Educ. Incomplete 19

Secondary School Completed 15

Others (Higher Certificates) 14

Total

160

\section{Family size}

$0-4$

$5-9$

$10 \&$ above

Total

Occupation

Weaving

Farming \& Trading

Farming

Trading

Farming \& Weaving

Civil Service \& Farming Total

Source: Field Survey, 2006
Percentage

0.63

25.24

68.13

5.62

100.00

16.25

73.12

7.50

3.13

100.00

13.13

23.12

33.75

11.88

9.38

8.75

100.00

41.88

53.12

5.00

100.00

1.25

24.38

51.25

0.62

1.25

21.25

100.00 


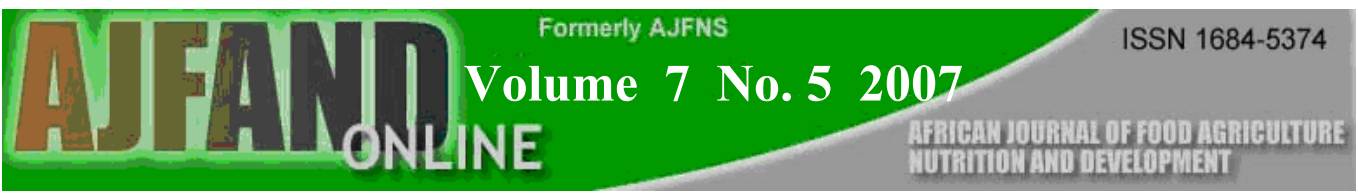

Table 2: Availability and Number of Rural Development Programmes

S/No. PROGRAMMES

1. Agricultural Development Programme YEAR OF COMMENCEMENT (ADP)

2. Directorate of Food, Roads and Rural 1986 Infrastructure (DFRRI)

3. Better life for Rural Women Programme 1987 (BLP)

4. Family Support Programme (FSP)

1995

5. Family Economic Advancement 1997

Programme

6.. $\quad$ Abia State community - based Poverty 2000 Reduction Programme (ABCPRP)

7. National Special Programme on Food 2001 security (NSPFS)

Source: Field Survey, 2006

Table 3: Frequency Distribution of Respondents according to Awareness in Rural Development Programmes

AWARENESS

Yes

No

Total
FREQUENCY

105

55

160
PERCENTAGE (\%)

66.63

34.37

100.00

Source: Field Survey, 2006 
Table 4: Frequency Distribution of Respondents According to Participation of Rural Development Programmes

\begin{tabular}{llcc}
\hline S/No & Rural Development Programmes & Frequency & \% of the categories \\
\hline 1. & ADP & 83 & 79.05 \\
$\mathbf{2 .}$ & FSP & 2 & 1.90 \\
$\mathbf{3 .}$ & Combinations: ADP \& FSP & 4 & 3.81 \\
$\mathbf{4 .}$ & ADP, FEAP \& FSP & 2 & 1.90 \\
$\mathbf{5 .}$ & ADP \& FEAP & 5 & 4.76 \\
$\mathbf{6 .}$ & ADP \& DFRRI & 3 & 2.86 \\
$\mathbf{7 .}$ & FSP, ADP, FEAP \& BLP & 1 & 0.95 \\
$\mathbf{8 .}$ & ADP, FEAP \& DFRRI & 1 & 0.95 \\
$\mathbf{9 .}$ & ALL & 4 & 3.81 \\
& Total & 105 & 100.00 \\
\hline
\end{tabular}

Source: Field Survey, 2006 
Table 5: Results of Paired t-test for levels of production, productivity, farm income and farm size

\begin{tabular}{|c|c|c|c|c|}
\hline \multirow[t]{2}{*}{ Categories } & \multicolumn{3}{|c|}{ Paired Differences } & \multirow{2}{*}{$\mathbf{t}$} \\
\hline & Means & Std. Deviation & Std. Error means & \\
\hline Pair $1 \begin{aligned} & \mathrm{X}_{1} \\
& \mathrm{X}_{2} \\
& \mathrm{X}_{1}-\mathrm{X}_{2}\end{aligned}$ & $\begin{array}{l}3.6628 \\
0.5707 \\
3.09\end{array}$ & 20.33 & 2.77 & $1.12^{* *}$ \\
\hline Pair $2 \begin{array}{r}X_{3} \\
X_{4} \\
X_{3}-X_{4}\end{array}$ & $\begin{array}{l}0.3109 \\
0.6220 \\
0.32\end{array}$ & 0.72 & 9.82 & $-3.17^{*}$ \\
\hline $\begin{array}{r}\text { Pair } 3 X_{5} \\
X_{6} \\
X_{5}-X_{6}\end{array}$ & $\begin{array}{l}5.4815 \\
1.7474 \\
3.73\end{array}$ & 15.05 & 2.05 & $1.83^{\star *}$ \\
\hline $\begin{array}{r}\text { Pair } 4 X_{7} \\
X_{8} \\
X_{7}-X_{8}\end{array}$ & $\begin{array}{l}46748.370 \\
13044.722 \\
33703.65\end{array}$ & 28644.97 & 3896.09 & $8.65^{*}$ \\
\hline
\end{tabular}

Source: Computed from Field Survey, 2006

* Significant at $5 \%$ level

* * Not significant at $5 \%$ level

$\mathrm{X}_{1}=$ Total Production (Tonnes) of Beneficiaries

$X_{2}=$ Total Production (Tonnes) of non -Beneficiaries

$X_{3}=$ Productivity (Total Output per hectare) in tonnes of Beneficiaries

$\mathrm{X}_{4}=$ Productivity (Total Output per hectare) in tonnes of non-Beneficiaries

$X_{5}=$ Farm size (hectares) of Beneficiaries

$\mathrm{X}_{6}=$ Farm size (hectares) of non - Beneficiaries

$X_{7}=$ Farm Income (Naira) of Beneficiaries

$X_{8}=$ Farm Income (Naira) of non - Beneficiaries 


\section{REFERENCES}

1. Elumilade DO, Asaolu TO and SA Adereti Appraising the Institutional Framework for Poverty Alleviation Programmes In Nigeria. International Journal of Finance and Economics Vol. 3:66 - 77, 2006

2. Howard PZ Investing in Agriculture as an Engine of Economic Growth: Uncovering determinants of the World Bank's Rural Development Strategy. Department of political science Annual Students' Conference. Columbia University, April 15, 2005

3. NAPEP. National Poverty Eradication Programme www. napep.org. Assessed 20/1/06. 2006.

4. NPC. National Planning Commission www.npc.org. Assessed 15/12/05 2005 FOS. Federal Office of Statistics National Consumers Survey. 1985/86 1992/93. FOS publication Lagos, 1994

5. World Bank. World Development Report (New York and Washington). Oxford University Press and World Bank, 2000

6. Ogunsanwo G What Promise Democracy? The Comet May 6, 2001

7. World Factbook Nigeria at a glance. www.cia.gov/publication. Accessed 8/25/05 2004.

8. Eboh EC, Okoye CU and D Anyichi Rural Development in Nigeria: Concepts, Processes and Prospects. Autocentury Publishers Enugu, 1995

9. Njoku JE Governance, Management and Partnership Imperatives for Sustainable Agricultural Research, food Security, Poverty Alleviation and Rural Development in Nigeria. Proc. Of National Workshop on Agriculture and Rural Development at NRCRI Umudike Abia State. May $22^{\text {nd }}-26^{\text {th }} 2000$.

10. Ijere MO and JA Mbanasor The Challenges of Change in Local Government for Poverty Alleviation and Rural Development. Proceedings of a National Workshop on Agriculture and Rural development held on $22^{\text {nd }}-26^{\text {th }}$ May at National root Crops Research institute Umudike, Abia State Nigeria, 2000.

11. Michener NJ The Participatory Approach: Contradiction and Co - option in Burkina Faso. World Development Vol.26 No. 12, 1998.

12. Mansuri G and V Rao Community - Based and Driven Development: A Critical Review. The World Bank Research Observer Vol. 19 No. 1, 2004.

13. Ekpo AH and O Olaniyi Rural Development In Nigeria: Analysis of the impact of the Directorate for Food, Roads and Rural Infrastructure (DFRRI) 1986-93 In:

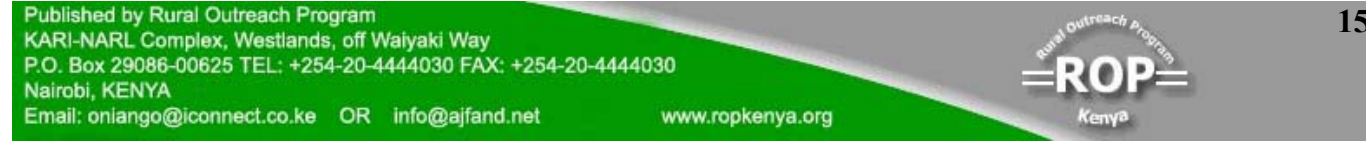


Rural Development In Nigeria: Concepts, Processes and Prospects. Autocentury Publishers Enugu, 1995.

14. Oyesanmi O, Eboiyehi F and A Adereti Evaluation of the Concepts, Implementation and Impact of Poverty Alleviation Programmes in Nigeria. Paper presented at the Centre for Gender and Social Policy studies. Nigeria: Obafemi Awolowo University Press. 2006.

15. Obasi IN and D Oguche Innovative Programmes in Rural Development in Nigeria: An Evaluation of the Better Life Programmes using the APBS Framework. In: Rural Development In Nigeria: Concepts, Processes and Prospects. Auto century Publishers, Enugu 1995.

16. Odunirepo O FEAP to boost Rural Development. Daily Times. 31 - 35 Feb. 2, 1998.

17. FMARD. Federal Ministry of Agriculture and Rural Development Special Programme on Food Security. www.pcuagric.org 1 - 9 Accessed 15/3/05 2001.

18. Abia State Agency for Community - Based Poverty Reduction Project Manual Of Operation. Abia state Government Press Nigeria, 2003

19. Nwagbo EC Impact of Institutional Credit on Agriculture in Funtua LGA, Katsina State, Nigeria. Samaru Journal of Agricultural Research Vol. 6: 79 - 86, 1986.

20. Ezeh CI A Comparative Study of Fadama and Non-Fadama crop Farmers in Osisioma-Ngwa LGA, Abia State, Nigeria. Journal of Tropical and Sustainable Agriculture Vol. 13: 31 - 36, 2004.

21. Mubarik A and JC Flinn Profit Efficiency among Basmati Rice Producers in Pakistan Punjab. American Journal of Agricultural Economics Vol. 71:303 - 310, 1998.

22. Anoyemi TT Gender Analysis for Sustainable Agriculture: The case of Nigeria. In: Y L Fabiyi and E O Idowu (eds). Poverty Alleviation and Food Security in Nigeria. NAAE Ibadan, 1999.

23. Okorji EC Dimension of Rural Poverty and Food Self - Sufficiency Gap in Nigeria .Poverty Alleviation and Food Security In Nigeria (eds) Y L Fabiyi and E O Idowu. Nigerian Assocaition of Agricultural Economists (NAAE) Ibadan, 1999

24. Njoku JE and MACA Odii Determinants of Loan Repayment under the Special Emergency Loan Scheme (SEALS) in Nigeria: A Case study of Imo State. Africa Review of Money, Finance and Banking Vol. 1: 39 - 52, 1991.

25. Nwosu F and M Odii Appraisal of Nigeria's Agricultural Development Programmes and Prospects For the $21^{\text {st }}$ Century. In: Agricultural Transformation 
in Nigeria. Proceedings of a National Conference in honour of Professor Martin O. Ijere held at the Federal University Of Agriculture, Umudike, Abia State. $24^{\text {th }}$ $-26^{\text {th }}$ August 1999.

26. Ezeh CI and CO Emerole Impact of Formal Rural credit Programmes in the Development Of Agriculture in Abia State, Nigeria: A Comparative Analysis of Borrowers and Non - Borrowers. Food and Fibre Production in Nigeria in the $21^{\text {st }}$ Century. Nwagbo, C C, Ukpabi, U H and A Anene (eds). Proc. Annual Conference of the College of Agriculture and Vet. Medicine, Abia State University. $10^{\text {th }}-13^{\text {th }}$ Sept. 2000 .

27. Amalu UC Poverty Alleviation and Agriculture in Sub - Saharan Africa: The Nigerian Experience. Journal of Food, Agriculture and Environment Vol. 3: 230 236, 2005. 